\section{Sciensage}

Journal of Advanced Scientific Research

Available online through https: / /sciensage.info
ISSN: 0976-9595

Research Article

DOI: $10.55218 /$ JASR. 202213126

\title{
STUDY OF COLLAGENASE PRODUCTION BY PENICILLUM SP. ISOLATED FROM DETERIORATED LEATHER SAMPLE
}

\author{
Savita Kate**1, Archana Pethe ${ }^{2}$ \\ ${ }^{\prime}$ Department of Biotechnology, Shivchhatrapati College, Aurangabad, Maharashtra, India \\ ${ }^{2}$ Department of Microbiology, Shivaji College of Arts, Commerce and Science, Akola, Maharashtra, India \\ *Corresponding author:savitaakate@gmail.com
}

\begin{abstract}
Collagenase production by Penicillium sp. isolated from deteriorated leather sample was studied. The isolate produced collagenase $802.43 \pm 15.81 \mathrm{U} / \mathrm{ml}$ at optimum temperature $30^{\circ} \mathrm{C}$ and at $\mathrm{pH} 6.5$ within 5 days using $1 \%$ collagen peptide type I as a substrate. $\mathrm{Ca}^{++}$ions were found to be the best activator whereas EDTA and $\beta$-mercaptoethanol inhibited collagenase production. The isolate was also found to produce caseinase, gelatinase and keratinase. Experimental results propose that the isolate having ability to produce broad range of enzymes can be effectively used as a tool for leather industry waste treatment.
\end{abstract}

Keywords: Leather, Collagen peptide type I, Metaloprotease, PMSF, Feather meal.

\section{INTRODUCTION}

Leather is utilized in making a large number of commercial commodities and it has gained a status symbol as one of the topmost foreign exchange earner and belongs to the elite of society. India is fortunate in having a good raw hide base [1] It has been indispensable item throughout history and is necessary to modern civilization in form of shoes, clothing, harness, machinery drive belts, hydraulic seals, bookbinding, sportsman jacket upholsty and endless other useful articles. Leather products are also used in industrial sectors [2]. The leather is an organic material that contains many nutrients for microorganisms. It is made up of $96.5 \%$ fibrous proteins and $3.5 \%$ are albumin and globulin. The fibrous proteins present in leather are collagen $(98 \%)$, elastin $(1 \%)$ and keratin $(1 \%)$. Leather Tanning is a general term use for numerous processing steps involve in converting animal hide and skins in to final leather [3]. Though in the process of making leather it is sought to remove as much of any other protein than collagen as possible. Leather is a stabilized collagen product therefore, leather is composed almost solely of collagen. Collagen is a major fibrous element of skin, bones, tendons, cartilage, blood vessels, and teeth, found in all multicellular organisms and is formed by the linking of amino-acids. The amino-acids are linked together with covalent peptide bonds between a carboxyl group and an amino group. The repetitive sequence of collagen (Gly-XY)n, where $\mathrm{X}$ and $\mathrm{Y}$ are commonly Proline and Hydroxyproline, can be proteolytically attacked only by enzymes with a sharply defined specificity profile [4] Leather is by definition a skin material of a vertebrate animal gone through a process of tanning to resist the natural process of decay [5]. The waste generated from a leather industry includes fleshing, chrome shaving, chrome splits, buffing dust skin trimmings and hair. Out of $1000 \mathrm{~kg}$ of raw hide used for leather making only $150 \mathrm{~kg}$ is converted into processed leather whereas remaining 850 $\mathrm{kg}$ remain as solid waste. About 6.5 million tons of wet salted hides are processed annually. The leather industry has commonly been associated with high pollution due to the bad smell, organic wastes and high water consumption caused during traditional manufacturing processes. Different forms of waste in quality and quantity, which emerge during the transformation of hides and skins into leathers in thousands of leather factories, from primitive to modern all around the world, have negative impacts on the environment. Leather industry dominates among them in generating voluminous pure as well as tainted collagen wastes amounting up to $600 \mathrm{~kg}$ per ton of skins/hides processed. Microorganisms can be used in order to degrade natural fibers like fur, leather wastes because they synthesized extracellular enzymes that can break chemical bonds in these materials. Some proteolytic 
enzymes, like collagenases, registered an increasing use for industrial applications in fur and leather industry because they are nontoxic and eco-friendly [6]. Collagenases are endopeptidase that digest native collagen in the triple helix region. Collagen is the major fibrous component of animal extracellular connective tissue. Unlike animal collagenases that split collagen in its native triple-helical conformation, bacterial collagenase is unique because it can degrade both waterinsoluble native collagens and water-soluble denatured ones. It can attack almost all collagen types, and is able to make multiple cleavages within triple helical regions. Studies report collagenase biosynthesis by fungi belonging to genera Aspergillus, Cladosporium, Penicillium and Alternaria. The Penicillium species have a greater biotechnological potential compared to the other genera mentioned, both for the production of proteases and other enzymes [7]. Aspergillus flavus, A. fumigatus, A.repens, Penicillium purpurogenum and P. frequentan, Cunnighamella elegans, P. chrysogenum, some pathogenic species of Aspergillus and Candida causing aspergillosis and candidiosis, some dermatophyte fungi, Histoplasma capsulatum var. capsulatum and var.dubosii, and Streptomycetes reported by Hamdy et al. [8] However, little was found in the literature about optimization of collagenase production by fungi.

The current study aims for the efficient collagenase production by Penicillium sp. isolated from leather samples. The objective of the present investigation is to accelerate leather digestion process by inoculating with collagenolytic species of Penicillium sp. isolated indigenously from leather samples.

\section{MATERIAL AND METHODS}

\subsection{Chemicals and Media}

Collagen peptide type I (TC343-10G), Nutrient broth (M002-100G), metal ions and organic solvents were obtained from Hi media Ltd., Mumbai. Phenylmethylsulphonyl fluoride [PMSF], Dimethylsulphoxide [DMSO], trichloroacetic acid was obtained from Sigma Chemical Co. USA.

\subsection{Isolation and identification of fungi}

The leather samples were collected from Kedar leather product, Aurangabad, M.S. The samples were collected by the IS: 5868-1969 methods by Tran [9] Samples were placed into sterilized polythene bags and brought to the laboratory.

Leather deteriorating fungi was isolated by inoculating collected deteriorated leather samples into potato dextrose broth (M403-Hi-Media) and incubated at $30^{\circ} \mathrm{C} \pm 2{ }^{\circ} \mathrm{C}$ for $5-7$ days. The initial isolation of fungi were carried out on potato dextrose agar (PDA). The colonies with different morphology, colour, and frequency were selected and the cultures were maintained on PDA agar slants at $4^{\circ} \mathrm{C}$ [10] Fungal isolates were identified by morphology, pigment produced and wet mount and confirmed by Raper K. B. [11]. Amongst the isolates, efficient fungal isolates producing all selected four enzyme (caseinase, gelatinase, keratinase and collagenase) were used for further study.

\subsection{Screening for enzyme production}

Well isolated colonies were used for screening their ability to hydrolyze collagen, keratin, gelatin and casein on collagen ( $1 \%$ collagen and $2 \%$ agar Hi-Media), feather meal $(1 \%)$, gelatin $(1 \%)$ and milk agar $(10 \%)$ plates respectively. Collagenase, Keratinase, gelatinase and caseinase producing fungi were confirmed by the presence of a clear zone around the fungal colonies. The plates were incubated at $30^{\circ} \mathrm{C}$ for 3 -5days. After incubation to each individual colony for collagenase and gelatinase activity, a drop of mercuric chloride precipitation reagent $\left(15 \mathrm{gm} \mathrm{HgCl}_{2}\right.$ in $20 \mathrm{ml}$ Conc. $\mathrm{HCl}$ volume make up to $100 \mathrm{ml}$ distilled water) was added. The fungi showing highest zone were picked up and purified by repeated screening on the same medium [12, 13] Collagen is a major protein of leather hence further study was concentrated on collagenase production [14].

\subsection{Collagenase production}

Triplicate set of $250 \mathrm{ml}$ flasks were inoculated with 1 disc $(6 \mathrm{~mm})$ of 5 days old fungal isolate in a fermentation medium of composition glucose $20 \mathrm{~g} / \mathrm{L}$, collagen $10 \mathrm{~g} / \mathrm{L}$, $\mathrm{NaH}_{2} \mathrm{PO}_{4} ; 0.5 \mathrm{~g} / \mathrm{L}, \mathrm{K}_{2} \mathrm{HPO}_{4} ; 0.5 \mathrm{~g} / \mathrm{L}$. The flasks were incubated at $30^{\circ} \mathrm{C}$ for 3 days in an orbital shaker at 150 rpm. Fermentation medium was centrifuged at $4{ }^{\circ} \mathrm{C}$ and $4000 \mathrm{rpm}$ for $10 \mathrm{~min}$, the supernatant filtrate serve as crude collagenase preparation $[8,15]$ and used for assay.

\subsection{Enzyme assay}

Collagenolytic activity was measured according to the Hamdy [8] method. 5mg collagen type I was used as substrate. $50 \mu \mathrm{l}$ enzyme filtrate was mixed with $250 \mu \mathrm{l}$ substrate in Tris $\mathrm{HCl}$ buffer-7.5 $\mathrm{pH}(50 \mathrm{mM})$ and incubated for 10 minute at $37^{\circ} \mathrm{C}$. Trichloroacetic acid (Merk); 0.2M, was added and incubated for 10 minute at $37^{\circ} \mathrm{C}$ followed by centrifugation at $4000 \mathrm{rpm}$ for 10 
minute. The supernatant $(0.2 \mathrm{~mL})$ was mixed with $0.5 \mathrm{~mL}$ of ninhydrin solution, boiled for $15 \mathrm{~min}$, cooled at room temperature for $5 \mathrm{~min}$, and the mixture was diluted with $5 \mathrm{~mL}$ of $50 \%$ (by volume) ethanol, then absorbance was measured at $575 \mathrm{~nm}$. One unit (U) of enzyme activity equals to one micromole of L-leucine equivalents released from collagen under specified conditions. Enzyme assay were performed in triplicates and the average rates were calculated to represent the enzyme activity.

\subsection{Optimization of collagenase production}

The collagenase produced by microorganisms is preferable because of its biochemical diversity. The enzyme is extracellular which makes it particularly easy to recovery at the end of fermentation. The influence of percent inoculum was studied by adding 1, 2, 3, 4 disc per $25 \mathrm{ml}$ of medium at various incubation times such as $72,96,120,144$ and $196 \mathrm{~h}$. The optimization of substrate concentration for collagenase production was done at different concentrations of collagen type I $0.5 \%, 1 \%, 1.5 \%, 2 \%$ and $2.5 \%$ in the production media as a substrate. Effect of $\mathrm{pH}$ and temperature on collagenase production was individually tested by taking the production media at different $\mathrm{pH}$ ranging from 5 to 8.5 and temperature from $10^{\circ} \mathrm{C}$ to $45^{\circ} \mathrm{C}$, as mentioned [7, 16-19] Abiotic control (without fungi), were always included. Amount of collagenase enzyme was checked every day till a decline was observed in the enzyme activity.

\subsection{Effect of metal ions and chemicals}

The sensitivity of various metal ions, organic solvents and inhibitors was studied by adding $1 \mathrm{mM} \mathrm{MnCl}_{2}$, $\mathrm{ZnCl}_{2}, \quad \mathrm{HgCl}_{2}, \mathrm{CuSO}_{4}, \quad \mathrm{MgCl}_{2}$, sodium sulphite, cysteine, PMSF (serine protease inhibitor), EDTA (metaloprotease inhibitor), lead acetate, $\mathrm{FeCl}_{3}, \mathrm{COCl}_{2}$, $\mathrm{CaCl}_{2}$ and $1 \%$ concentration of $\beta$-mercaptoethanol, glycerol, DMSO in the fermentation media. The effect of them was measured by assaying activity every day for a period of three days. Collagenase activity measured in the absence of any inhibitor or metal ions was taken as $100 \%$ relative activity as mentioned [17, 18]. The aliquots of the samples were subjected to centrifugation and were used for assay. All experiments were carried out in triplicates. Abiotic control (without fungi) was always included. Amount of collagenase enzyme was checked every day till a decline was observed in the enzyme activity.

\subsection{Efficiency of leather digestion by Penicillium sp.}

Triplicate set of minimal media $\left(\mathrm{KH}_{2} \mathrm{PO}_{4} ; 0.4 \mathrm{~g} / \mathrm{L}\right.$, $\mathrm{K}_{2} \mathrm{HPO}_{4} ; 1.4 \mathrm{~g} / \mathrm{L}, \mathrm{NaCl} ; 0.5 \mathrm{~g} / \mathrm{L}$ and $\mathrm{MgSO}_{4} ; 0.01 \mathrm{~g} / \mathrm{L}$ ) test tubes containing leather samples as a substrate were inoculated with 1 disc $(6 \mathrm{~mm})$ of 5 days old Penicillium sp. culture and the tubes without fungi (abiotic controls), were incubated at $30 \pm 2^{\circ} \mathrm{C}$ for 5 days in an orbital shaker at $160 \mathrm{rpm}$. Amount of leather deterioration by fungi were analyzed after 5 days of incubation. The aliquots were centrifuged at $4^{\circ} \mathrm{C}$ and 8000rpm for $10 \mathrm{~min}$ and the supernatant filtrate was used to evaluate leather deterioration by released of amino acids by a modified method of Moore [20] at 575nm. One proteolytic unit was defined as the amount of enzyme that released $1 \mu$ mole of leucine substrate released per $\mathrm{h}$.

\subsection{Statistical analysis}

Data were analyzed by one way ANOVA (analysis of variance). Readings were considered significant at $P \leq 0.05$.

\section{RESULTS AND DISCUSSION}

\subsection{Isolation and identification of fungi}

Out of 73 fungal isolates 11 (Aspergillus niger, Aspergillus nidulans, Aspergillus flavus, Penicllium sp., Paecilomyces varioti, Paecilomyces varioti bainer, Rhizopus sp., Aspergillus fumigatus, Alternaria tennuissima, Trichoderma sp. and Aspergillus terreus) capable to hydrolyze keratin, collagen, gelatin and casein were used for advance study. They were identified by wet mount and confirmed by recognized Botany lab, Aurangabad (M.S.). Most efficient collagen hydrolyzing fungi was screened by quantitative assay. Penicllium sp. was found to be more efficient leather deteriorating among isolates, hence selected for further study. The results obtained from the leather articles indicated that the maximum fungi were isolated from leather articles in (Buff) and chrome tanned leather (Goat) and relative deteriorated leather samples were recorded for Aspergillus niger, $A$. flavus, A. fumigatus, Paecilomyces variola and P.citrinum etc. [21].

\subsection{Enzyme assay}

Penicillium sp. showed collagenase production 781士 $9.54 \mathrm{U} / \mathrm{ml}$ after $120 \mathrm{~h} .379 .80 \mathrm{U} / \mathrm{ml}$ One unit $(\mathrm{U})$ of enzyme activity equals to one micromole of L-leucine equivalents released from collagen under specified conditions. 


\subsection{Optimization of collagenase production}

The effect of various physiochemical conditions such as inoculum size, incubation period, substrate, $\mathrm{pH}$ and temperature on collagenase production were studied by using isolate. All parameters were studied in triplicates.

\subsection{Effect of Inoculum size and incubation period}

In present work, Penicillium Sp. $(822 \pm 19 \mathrm{U} / \mathrm{ml})$ showed optimum collagenase production by using 1 disc of $6 \mathrm{~mm}$ (5 days old culture) after 5 days of incubation (Fig. 1). The isolate, initially all inoculum (1disc-4disc) showed near about same collagenase production but as incubation increases 1, disc inoculum was optimum inoculum for collagenase production by selected fungi.

\subsection{Effect of incubation period}

Collagenase production by the isolate was initiated on $2^{\text {nd }}$ day $(340.26 \pm 24)$ and maximum production was shown on $5^{\text {th }}$ day Penicillium Sp. $\left(814 \pm 15 \mathrm{U} / \mathrm{ml}\right.$, till $6^{\text {th }}$ day production was studied as decline started (Fig. 2. Similar to present study result was reported by Ali [22] Aspergillus oryzae NRRL-447 was able to grow and produced collagenase after 5 days incubation at $30^{\circ} \mathrm{C}$ at $150 \mathrm{rpm}$.

\subsection{Effect of substrate concentration}

The efficiency of collagenase production was studied by using substrate concentration ranging from $0.5 \%$ to $2.5 \%(\mathrm{w} / \mathrm{v})$. Penicillium sp. showed highest collagenase production $(781.39 \pm 15 \mathrm{U} / \mathrm{ml})$ at $1 \%$ collagen type I substrate after 5 days of incubation (Fig 3). In present studies, it was observed that initially highest concentration substrate showed highest collagenase production but as time increased decreased the enzyme production. High substrate concentration may cause repression of collagenase production [23] Fungal leather isolates showed highest collagenase production at $1 \%$ substrate concentration similar to the literature study.

\subsection{Effect of $\mathrm{pH}$}

The effect of $\mathrm{pH}$ on collagenase production was studied at $\mathrm{pH}$ range of 5 to 8.5, isolates showed highest collagenase production in $\mathrm{pH}$ range 6-6.5 $(814 \pm 15 \mathrm{U} / \mathrm{ml})$. Above this level, the collagenase production decreased, because the metabolic activities of microbes are very much responding to $\mathrm{pH}$ change,Lowest production of $276.59 \pm 19.93$ and $239.93 \pm 15$ was found at $\mathrm{pH} 5$ and 8.5 respectively by isolates (Fig 4).

\subsection{Effect of temperature}

Temperature plays an important role for the production of collagenase. The effect of temperature on collagenase production was studied by the incubating the culture media at various temperatures $10,30,40$ and $45^{\circ} \mathrm{C}$ for isolate (Fig 5). The isolate under study showed maximum enzyme production at mesophilic temperature $30 \pm 2^{\circ} \mathrm{C},(781.39 \pm 15 \mathrm{U} / \mathrm{ml})$ after 5 days of incubation as temperature increases collagenase production by fungi found to be decreased. Lowest collagenase production was found at $10^{\circ} \mathrm{C}$ and $45^{\circ} \mathrm{C}$.

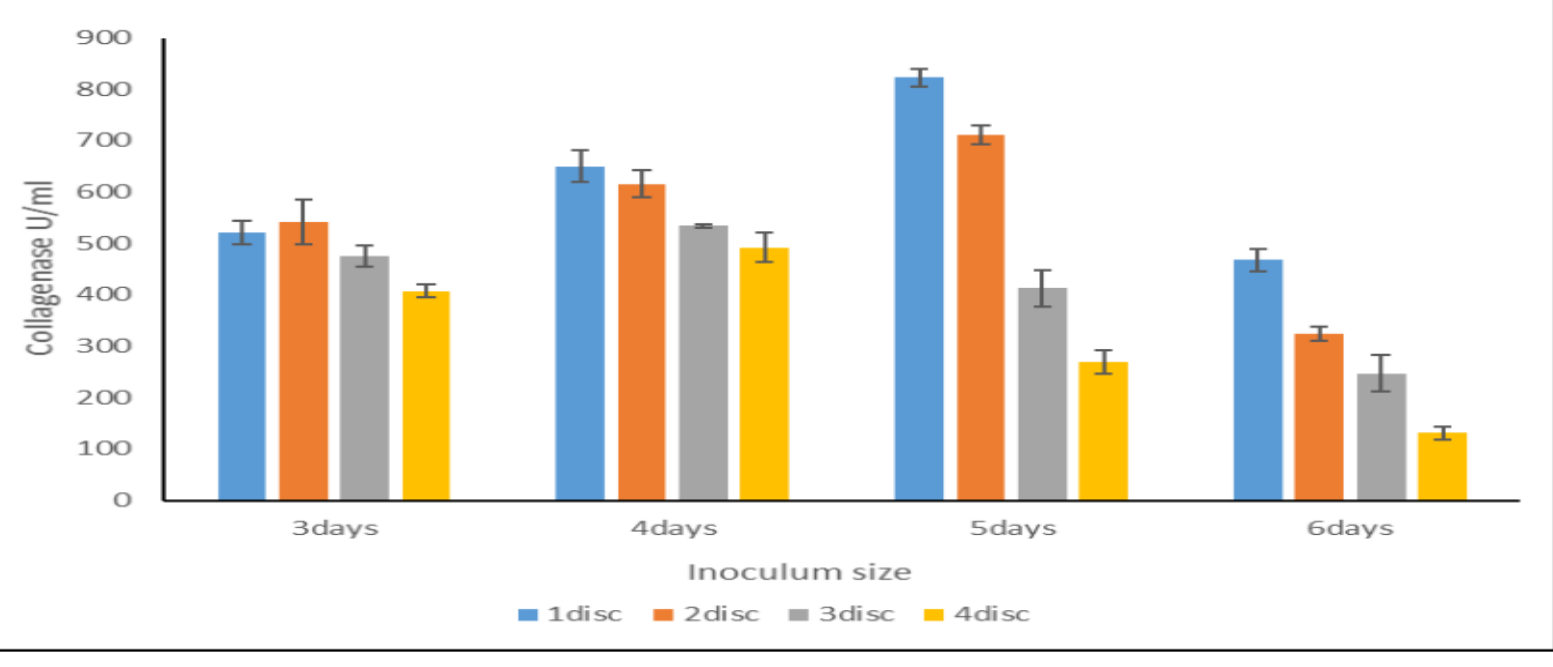

Fig. 1: Effect of Inoculum size on collagenase production by Penicillium sp. 


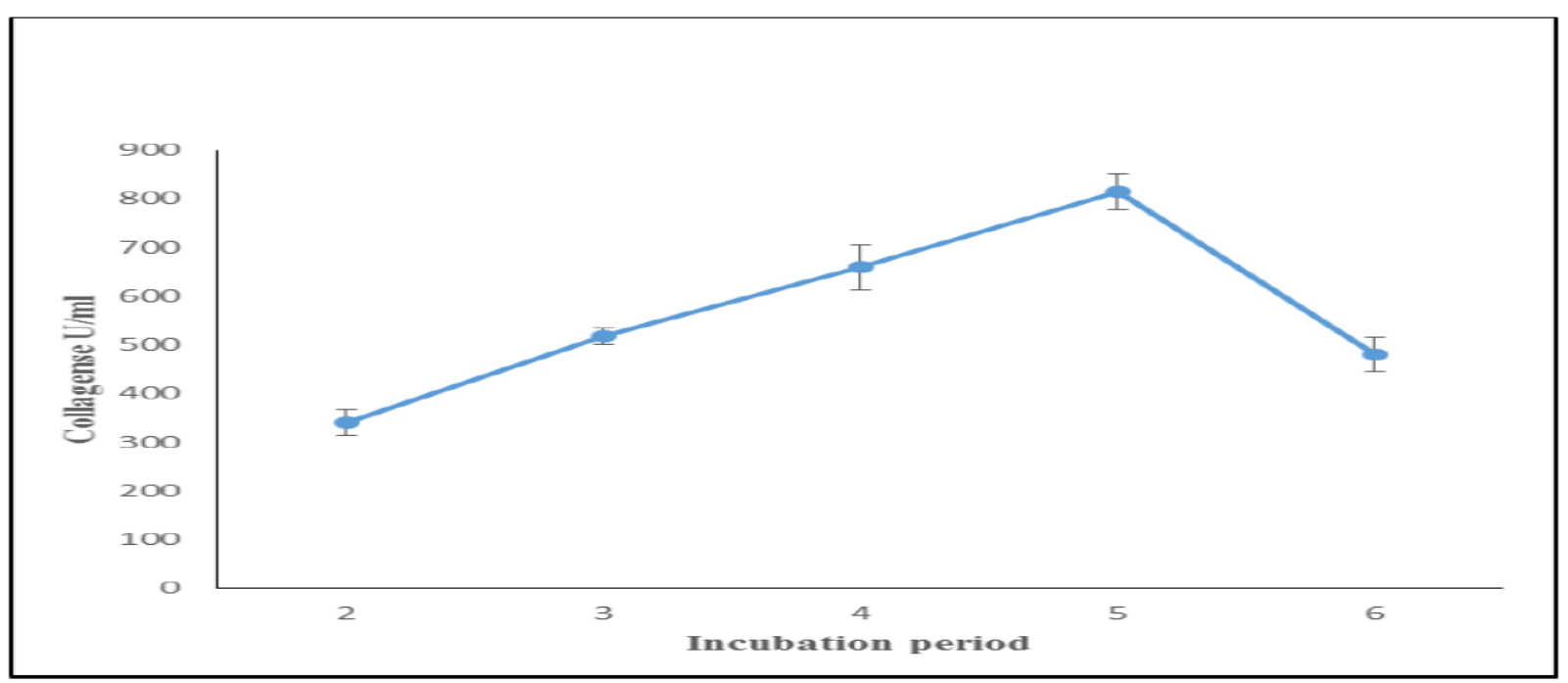

Fig. 2: Effect of Incubation on collagenase production by Penicillium sp.

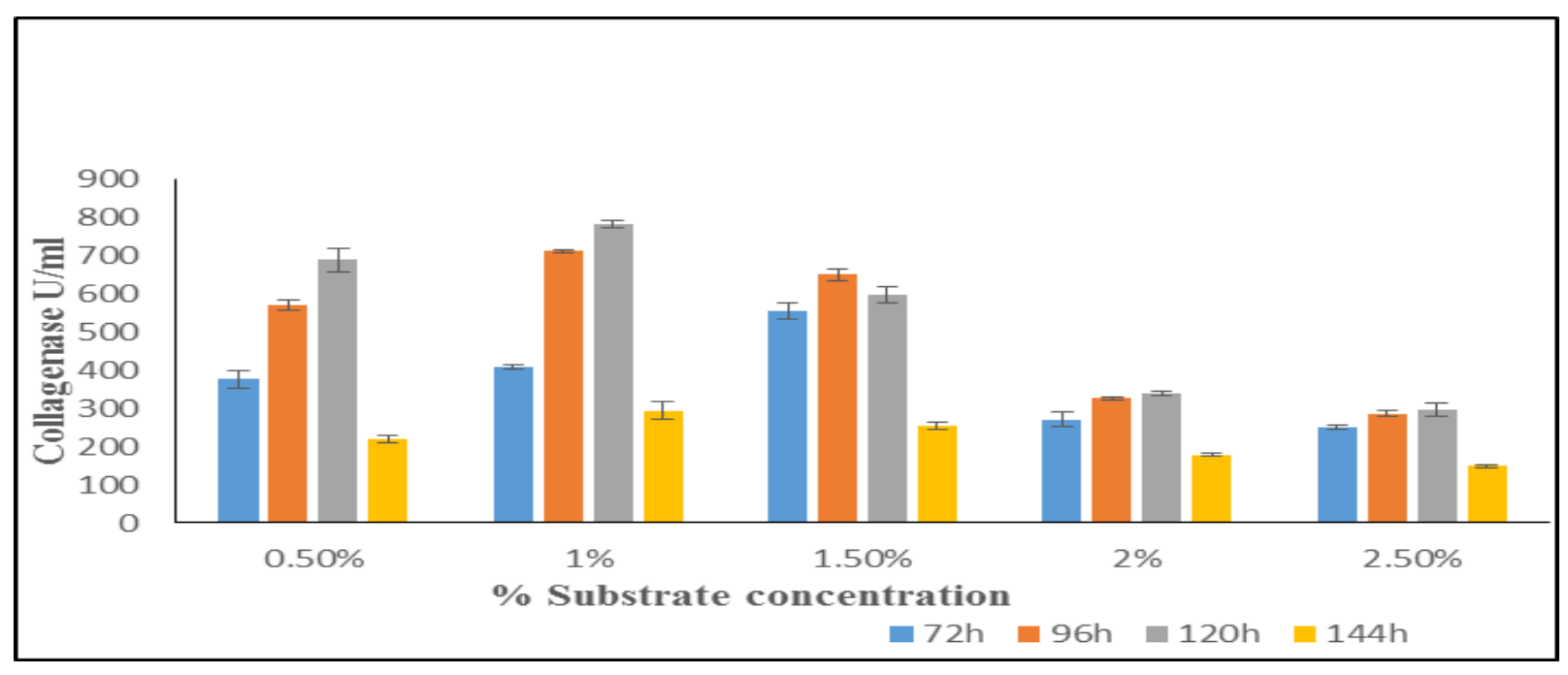

Fig. 3: Effect of substrate concentration on collagenase production Penicillium sp.



Fig. 4: Effect of pH on collagenase production by Penicillium sp. 


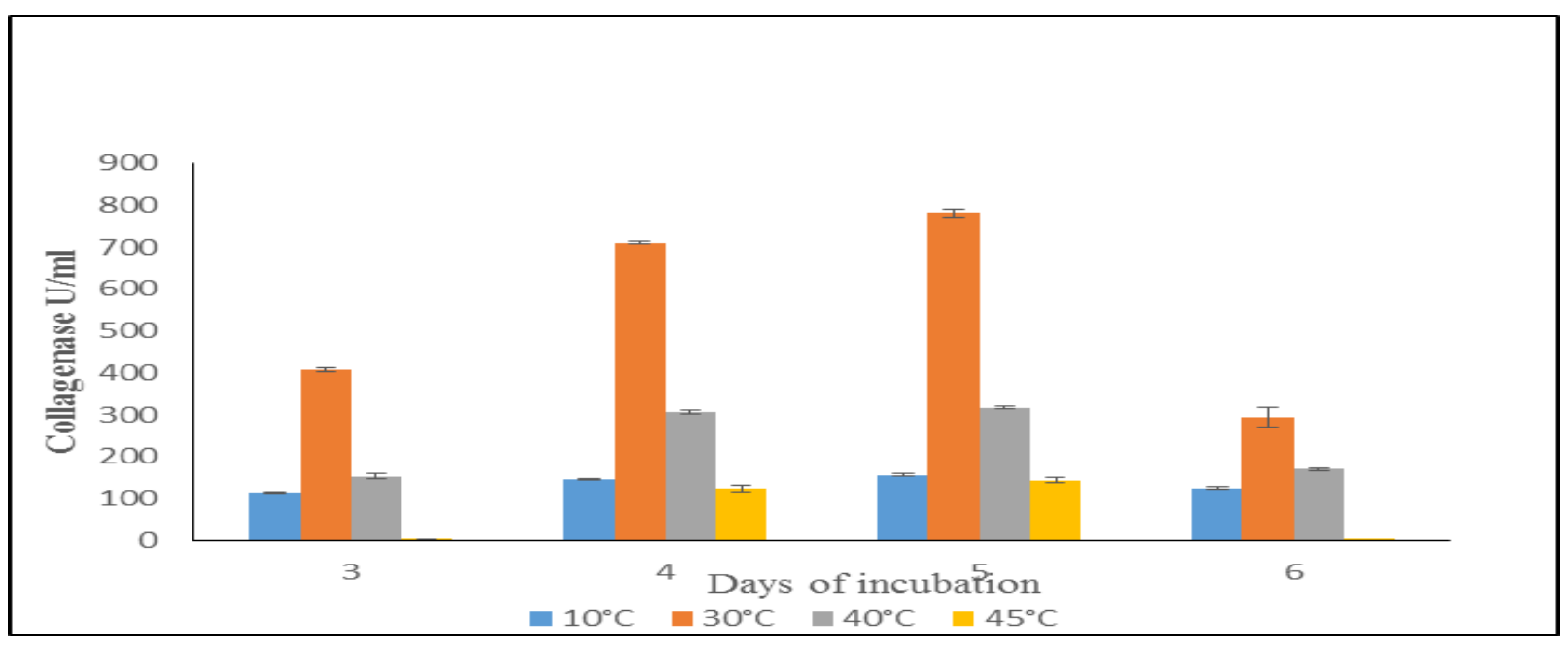

Fig. 5: Effect of Temperature on collagenase production by Penicillium sp.

\subsection{Effect of metal ions and chemicals}

The collagenase production by the isolate were strongly inhibited by $\mathrm{Hg}^{+2}$, EDTA and $\beta$-mercaptoethanol however $\mathrm{Fe}^{2+}, \mathrm{Zn}^{2+}, \mathrm{Ca}^{2+}$ and DMSO enhanced its production but not by PMSF (Fig. 6). EDTA, a chelating agent for calcium ions strongly inhibited enzyme activity therefore given fungal collagenase was a member of metalloprotease. Complete inhibition of enzyme production in presence of mercaptoethanol indicating that structure of this enzyme contained disulphide. PMSF and DMSO, showed very little or no effect on collagenase production. Magnesium ions and $\mathrm{CaCl}_{2}$ stimulated collagenase production with relative activity $104 \%-115 \%$ respectively. Some partially inhibited or stimulated by $\mathrm{Zn}, \mathrm{Cu}$ metal ions and cysteine chloride, sodium sulphite. Same result shown by Porphyromonas gingivalis, EDTA also inhibited collagen degradation, but there was no effect on the activity when the enzyme was incubated with PMSF. On the other hand, $\mathrm{Ca}^{2+}$ stimulated the activity of the purified protein [24].

\subsection{Efficiency of leather digestion by Penicillium sp.}

The efficiency of leather deterioration by the isolate was analyzed by released amino acid on minimum media, deterioration of leather samples (raw and finished) started from fifth days of incubation (Fig. 7 and 8) and leather samples showed tremendous deterioration into hair like structure by Penicllium sp. after fifteen to twenty days of incubation and after one month of incubation complete deterioration was observed.

Hence, the fungal isolate found to be efficient in collagenase production and can be used for leather waste treatment and commercial production of collagenase with additional study.

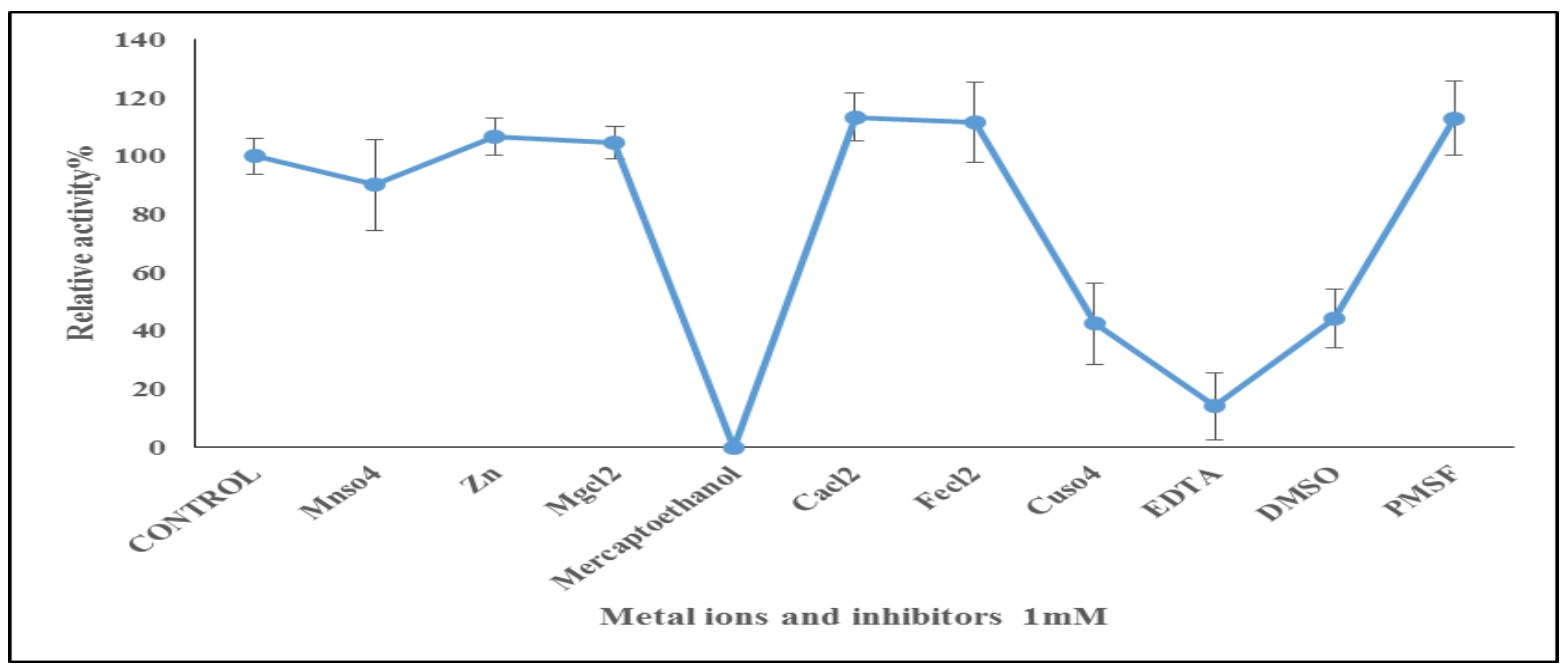

Fig. 6: Effect of Metal ions and inhibitors on collagenase production by Penicillium sp. 


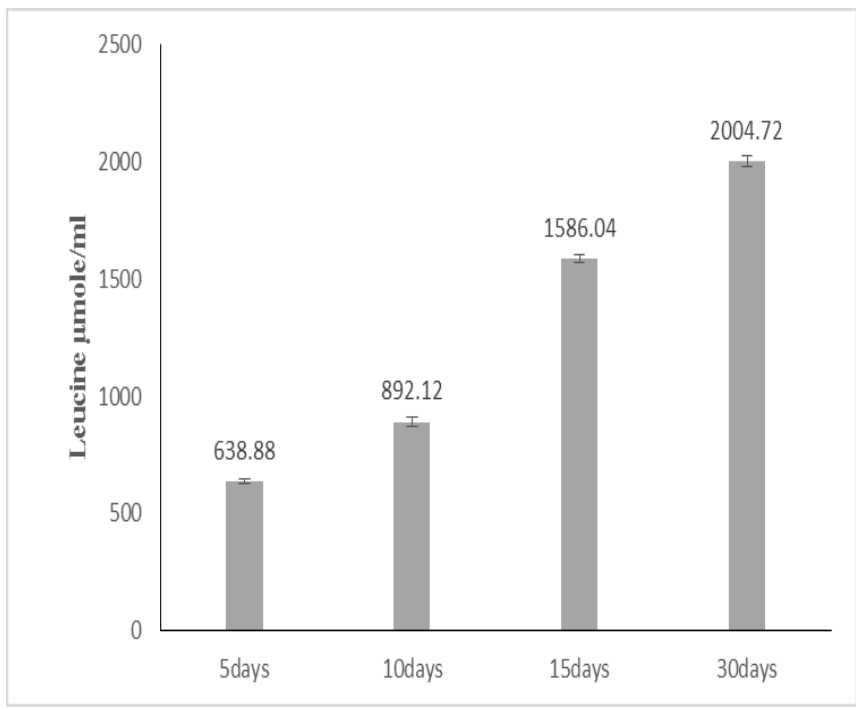

Fig. 7: Effiency of leather deteriorations by Penicillium sp.

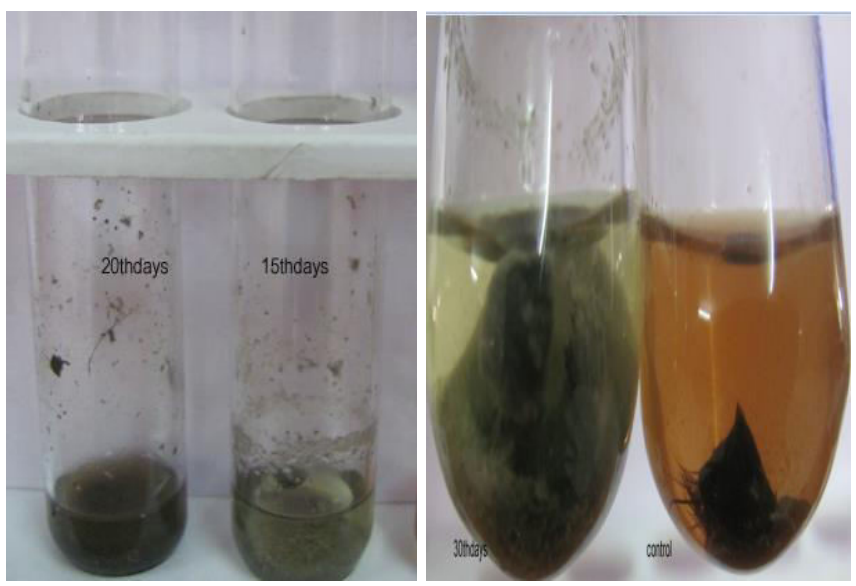

Fig. 8: Effiency of leather deteriorations by Penicillium sp.

\section{CONCLUSION}

Penicillium sp. isolated from deteriorated leather sample produced collagenase $802.43 \pm 15.81 \mathrm{U} / \mathrm{ml}$ after 5 days incubation at $30^{\circ} \mathrm{C}$ using $1 \%$ collagen peptide type $\mathrm{I}$ as a substrate at $\mathrm{pH}$ 6.5. In presence of $1 \%$ EDTA and $\beta$ mercaptoethanol collagenase production was shown to be inhibited. Experimental outcomes propose that the Penicllium sp. showed tremendous deterioration into hair like structure after fifteen to twenty days of incubation. Hence, can be used as an ecofriendly agent for leather industry waste treatment.

\section{ACKNOWLEDGEMENT}

We acknowledge Dr. P. V. Ashtekar, Principal, Shivchhatrapati College, Aurangabad, for giving permission to carry out the proposed work in the Institute \& sparing the facilities.

\section{Conflict of interest}

Authors declare no conflict of interest.

\section{REFERENCES}

1. Rathore DS, Research Journal of Recent Sciences, 2015; 4: 228-234.

2. Jaouadi N, Hatem R, Abdelmalek B, Sahar T, et al. PLOSOne, 2013; 8(10):1-17.

3. Tissier $\mathrm{C}$ and Chensais $\mathrm{M}$, Emission scenario Documents, 2000; 1-14.

4. Ludwick L. Program in Integrated Conservation of Cultural Property Graduating thesis, BA/Sc; 2012.

5. Thomson R. Journal of the society of Leather Technologist and chemists, 2006; 90(4):137-145.

6. Khandelwal S, Bhavar S. An ecofriendly approach, Proceedings of DBT sponsored National Conference on Modern Analytical Technique in Microbiology, 2014; 79-84.

7. Wanderley M, Carolina A, Carolina L, Silverio S, et al. Xx Simposio Nacional De Bioprocessos Xi Simposio De Hidrolise Enzimatica De Biomassa Fortaleza, Ceara, Brasil, 2015.

8. Hamdy H, Indian Journal of Biotechnology, 2008; 7:333-340.

9. Anonymous, Indian standards methods for leather sampling, IS5868: ISI, New Delhi, 1969; 13.

10. Awasthi P, Kushwaha R. International Journal of Pharmaceutical \& Biological Archives, 2011; 2(6):17451750.

11. Raper K, Thom C. Indian reprint, International books and periodicals supply service, Delhi , 1984; 875.

12. Shivkumar T, Ramasubramanian V, Arasu V.Insight Bacteriol, 2012; 1 (1):1-6.

13. Mozotto A, Melo C World J. Biotech., 2011; 27(1):1355-1365.

14. Lili L, Meihu M, Zhaoxia C, Xieli Y, et al. Food Technol. Biotechnol, 2010;48(2):151-160.

15. Sayed M, Tahany M, Abdel R, Magda M, et al. Jordan Journal of Biological Sciences, 2012;5(4):321-330.

16. Lima C, Lima F, Neto B. Biotechnol Bioprocess Eng, 2011; 16: 549-560.

17. Balan D, Florentina I, Petruta C, Evelina G, et al.Scientific Bulletin Series F. Biotechnologies, 2013; 17:160-163.

18. Baehaki A, Maggy T, Suhartono S, Syah D, et al. African Journal of Microbiology Research., 2012; 6(10):2373-2379. 
19. Daboor M, Budge M, Ghaly E. Advances in Bioscience and Biotechnology., 2012;3:191-203.

20. Moore S. J. Biol. Chem., 1968; 243:6281-6283.

21. Rathore D, Sharma N, Chauhan S. Int.J.Curr. Microbiol. App. Sci., 2013; 2(4):74-83.

22. Ali Y, Neto H, De Souza M, Hamilton C. African Journal of Biochemistry Research, 2013; 7(8):146-157.
23. Wang B, Yang K, Lin C, Zhang Y, et al. The Society for Applied Microbiology, Letters in Applied Microbiology, 2006; 42:589-594.

24. Park J, Lee S, Byun H, Kim H, et al. Journal of Biochemistry and Molecular Biology, 2002; 35(6):576582. 